2.Bailey, J.E., N.A. Da Silva, S.W. Peretti, J.H. Seo and F. Srienc. 1986. Studies of hostplasmid interactions in recombinant microorganisms. Ann. NY Acad. Sci. 469:194-211.

3.Lerner, C.G. and C.D. Carter. 1995. PCR colony screening using the scintillation proximity assay to detect inserts in cloning vectors. BioTechniques 19:914-917.

4.Liu, Z. and N.C. Mishra. 1995. Single-tube method for plasmid miniprep from large numbers of clones for direct screening by size or restriction digestion. BioTechniques 18:214217.

5.Sambrook, J., E.F. Fritsch and T. Maniatis. 1989. Molecular Cloning: A Laboratory Manual, 2nd ed. CSH Laboratory Press, Cold Spring Harbor, NY.

This work was supported by Grant No. 9502235 from the National Science Foundation. Address correspondence to Roger G. Harrison, University of Oklahoma, School of Chemical Engineering and Materials Science, 100 East Boyd Street, Norman, OK 730190628, USA. Internet: rharrison@ou.edu

Received 15 July 1997; accepted 23 September 1997.

Gregory D. Davis and Roger G. Harrison

University of Oklahoma

Norman, OK, USA

\section{Versatile Low-Copy- Number Plasmids for Temperature-Inducible Overexpression of Bacterial Genes in Escherichia coli}

BioTechniques 24:362-366 (March 1998)

Today, many plasmids for expression studies in strains of Escherichia coli are available. Most of them are based on high-copy-number vectors like pBR322 or the pUC-series plasmids. Transcription of the gene of interest is commonly initiated from powerful promoters whose activity is controlled by an inactivatable repressor. The gene encoding the repressor is either located in the host chromosome, on a compatible co-plasmid or directly on the expression vector, which increases the number of suitable hostvector combinations.

One of the most popular promoter systems for use in expression studies is the lac-UV5 promoter, a catabolite-insensitive mutant of the E. coli lac operon promoter $p_{\text {lac }}(10)$. Initiation of transcription from lac-UV5 and $p_{\text {lac }}$ is controlled by the lacI repressor, which is inactivated by addition of isopropyl $\beta$-D-thiogalactopyranoside (IPTG). However, induction of promoter activity with IPTG is expensive and therefore sometimes not suitable when using bacterial expression systems in a largescale bioreactor process. In these cases, the thermoinducible $c$ I857- $p_{\mathrm{R}}$ or $c$ I857$p_{\mathrm{L}}$ promoter-repressor systems derived from bacteriophage lambda serve as alternatives (8). Transcription from the powerful $p_{\mathrm{R}}$ promoter is repressed by the mutated lambda repressor encoded by the cI857 gene in cells growing at $30^{\circ} \mathrm{C}$. At an incubation temperature of $42^{\circ} \mathrm{C}$, the thermolabile repressor is inactivated, and transcription is enabled. Induction of the $\lambda-p_{\mathrm{R}}$ promoter can also be achieved by an alkaline $\mathrm{pH}$ shift of the growth medium (6), a method that can easily be used in fermentation bioreactors. These expression systems are suitable for high-level expression of heterologous proteins in $E$. coli leading up to $40 \%$ of total protein synthesized (8). However, a decreased growth rate of recombinant cells is often observed when expressing a cloned gene encod- ed by a multicopy plasmid and induced from a strong promoter (1). Respectively, high-level production of even a normal nontoxic product can be disadvantageous and can lead to decreased stability of the particular host-vector system (3). Because plasmid stability is obviously an essential prerequisite for successful expression of heterologous proteins, efforts were made to achieve stable host-vector associations.

However, only a few expression vectors based on low-copy-number plasmids are available for moderate overexpression in $E$. coli $(4,12)$, and none use a thermoinducible promoter-repressor system and show an increased plasmid stability.

Therefore, we have constructed a set of low-copy-number vectors with different unique restriction sites suitable for moderate overexpression of bacterial genes in strains of E. coli. These pSC101-derived plasmids combine the advantages of the thermoinducible $\lambda$ $c 1857-p_{\mathrm{R}}$ promoter-repressor system with an increased plasmid segregation stability. In addition, they are useful as co-plasmids for ColE1- and p15A-derived vectors in complementation studies. The $c 1857$ gene encoding the thermolabile lambda repressor is located on the expression plasmids to increase the versatility of the usable host-vector associations. In contrast to most of the other $\lambda$-cI857- $p_{\mathrm{R}}$ expression vectors, the $p_{\mathrm{R}}$ promoter lacks the ribosomal binding site and the start codon of the $\lambda$-cro gene. The exclusion of these features avoids the translation of a fusion

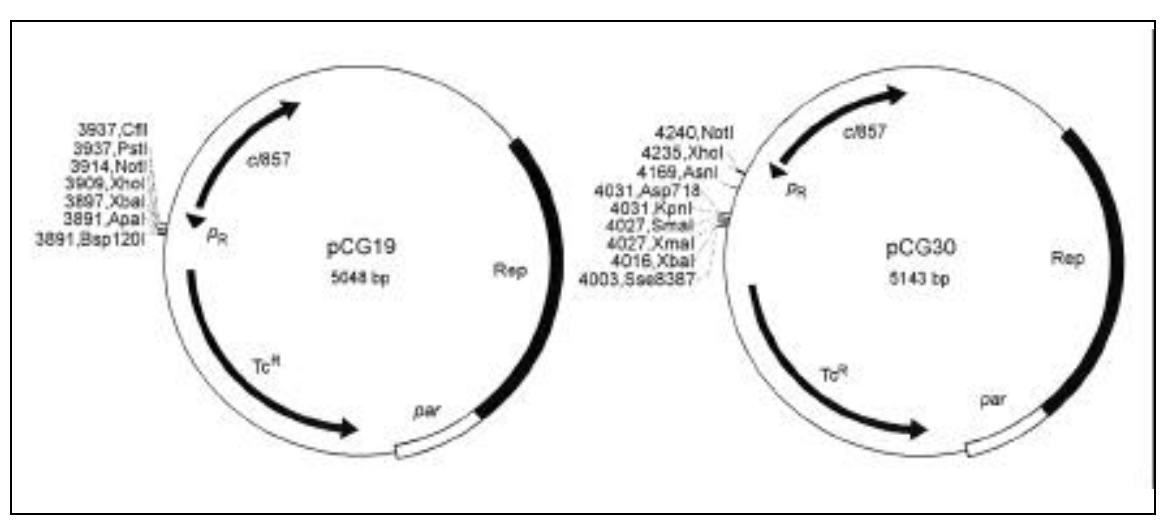

Figure 1. Restriction maps of the low-copy-number $c I 857-p_{\mathrm{R}}$ expression vectors pCG19 and pCG30. The plasmids contain a pSC101-derived origin of replication and the $\lambda$ - $p_{R}$ promoter controlled by the thermolabile $c I 857$ repressor. Only unique restriction sites that are useful for insertion of genes downstream of $p_{\mathrm{R}}$ are shown. The open boxes indicate the localization of the par locus, which is required for increased plasmid segregation stability. 
protein between $\lambda$-cro and the bacterial gene to be expressed. Improved segregational stability of the recombinant plasmids was obtained by use of the pSC101 replication origin, including the par locus. This 375-bp DNA fragment is critical for plasmid segregation (5) and partially reverses the negative effect of prolonged expression of genes encoded in high-copy-number vectors on the cell growth (2). Because of the stringent mode of replication, these vectors are maintained at about $6-8$ copies per genome (11).

All DNA manipulations during construction of the low-copy-number expression vectors were performed using standard methods (9), except for ligations for which Ready-To-Go $\mathrm{Go}^{\mathrm{TM}}$ T4 DNA Ligase (Pharmacia Biotech, Stockholm, Sweden) was used according to the manufacturer's instructions. Cells harboring $\lambda$-cI857- $p_{\mathrm{R}}$ plasmids were always grown at an incubation temperature of $30^{\circ} \mathrm{C}$ or below to keep the $p_{\mathrm{R}}$ promoter in a repressed state.

For construction of the described expression vectors, we isolated the $\lambda$ $c I 857-p_{\mathrm{R}}$ cassette from pCQV2 (7). Two oligonucleotide primers were designed based on the nucleotide sequence of bacteriophage lambda and used to amplify an 816-bp product containing the $c 1857$ repressor gene and the $p_{\mathrm{R}}$ promoter using polymerase chain reaction (PCR). The sequence of primers used is as follows: pCQV2_85C, 5'-GCAACCATTATCACCGCCAG-3' and pCQV2_4155, 5'-CGACCAGAACACCTTGCCGA-3'. These primers were chosen to amplify a product that contains the cI857 gene controlled by its natural promoter and the strong $p_{\mathrm{R}}$ promotor but lacks the ribosomal binding site and the start codon of the cro gene. The PCR product was cloned into the TA Cloning ${ }^{\circledR}$ Vector pCR ${ }^{\circledR}$ II (Invitrogen, Carlsbad, CA, USA). The obtained plasmid was termed pCG13. It contains a restriction site of the rare cutting enzyme NotI downstream of the $p_{\mathrm{R}}$ promoter, which is suitable for the insertion of genes under control of the $\lambda$-cI857- $p_{\mathrm{R}}$ expression system. The $\mathrm{pSC} 101$ replication origin and the genes coding for tetracycline resistance were isolated from pLG339 (11). This plasmid possesses a functional par locus at a minimized vector size. pLG339 (Accession No. 37131; ATCC,

Table 1. Induced Expression of CAT Protein by pCG30cat in E. coli Strain DH5 $\alpha$

\begin{tabular}{|cccccc|}
\hline $\begin{array}{c}\text { Time } \\
(\mathbf{h})\end{array}$ & $\mathbf{O D}_{\mathbf{6 6 0}}$ & $\begin{array}{c}\text { Plating } \\
\text { Efficiency } \\
(\%)\end{array}$ & $\begin{array}{c}\text { Protein } \\
\text { Concentration } \\
(\boldsymbol{\mu} \mathbf{g} / \mathbf{m L})\end{array}$ & $\begin{array}{c}\text { CAT } \\
\text { Concentration } \\
(\boldsymbol{\mu g} / \mathbf{m L})\end{array}$ & $\begin{array}{c}\text { CAT/Total } \\
\text { Protein } \\
(\%)\end{array}$ \\
\hline 0 & 0.3 & 100 & 365 & 0.04 & 0.01 \\
1 & 0.8 & 100 & 381 & 3.45 & 0.9 \\
2 & 1.6 & 100 & 436 & 6.05 & 1.4 \\
\hline
\end{tabular}

Cells were grown in $100 \mathrm{~mL}$ LBG medium (Luria broth with $20 \mathrm{~g} / \mathrm{L}$ glucose and 5 $\mathrm{mg} / \mathrm{L}$ tetracycline) at $30^{\circ} \mathrm{C}$ until an optical density $\left(\mathrm{OD}_{660}\right)$ of 0.3 was reached. The incubation temperature was then shifted to $42^{\circ} \mathrm{C}$, and the amount of CAT in the cells was measured 0,1 and $2 \mathrm{~h}$ after temperature shift. CAT concentration in the lysed cells was determined using the CAT ELISA according to the manufacturer's instructions. Total protein concentration was measured using the Coomassie ${ }^{\circledR}$ Protein Assay (Pierce Chemical, Rockford, IL, USA). Plating efficiency was determined by comparison of cfu on agar plates containing or lacking antibiotics. Similar results were obtained for DH5 $\alpha /$ pCG19cat (data not shown).

Rockville, MD, USA) was digested with EcoRI and $P v u \mathrm{II}$, and the 3.7-kb fragment was isolated after filling in the EcoRI site with the Klenow fragment of DNA polymerase I. This was ligated to the 1.3-kb $P v u I I$ fragment isolated from pCG13, obtaining the low-copy-number expression vector pCG19 (Figure 1). To increase the number of unique restriction sites, a 230-bp $P v u \mathrm{I} / K p n \mathrm{I}$ fragment was removed from pCG19 by re-ligation after DNA polymerase I exonuclease treatment. This plasmid was then digested with $X b a I$, treated with the Klenow fragment of DNA polymerase I and ligated to a 322-bp PvuII fragment from pUC18 containing the multiple cloning site. The obtained $\lambda-c 1857-p_{\mathrm{R}}$ expression vector was termed pCG30 (Figure 1).

The functionality of our low-copynumber expression vectors was ensured by expression of chloramphenicol acetyltransferase (CAT) under control of the $\lambda-c I 857-p_{R}$ expression system. A promoterless cat indicator gene (Chloramphenicol Acetyltransferase GenBlock $^{\circledR}$; Pharmacia Biotech, Piscataway, NJ, USA) was cloned into the NotI restriction site after treatment with the Klenow fragment of DNA polymerase I. E. coli DH5 $\alpha^{\mathrm{TM}}$ (Life Technologies, Gaithersburg, MD, USA) was transformed with the ligation mixture, and the temperature-inducible CAT expression of the obtained strains was determined using the CAT enzyme-linked immunosorbent assay (ELISA; Boehringer Mannheim $\mathrm{GmbH}$, Mannheim,
Germany). The results of the expression studies are shown in Table 1 and demonstrate that because of the sensitivity of the immunological test, it is possible to determine the amount of CAT produced even when the promoter is in a repressed state. At the time of temperature shift, less than $0.01 \%$ of total cellular protein is represented by $\mathrm{CAT}$, indicating that the lambda repressor tightly regulates the $p_{\mathrm{R}}$ promoter. Incubation of the cultures at $42^{\circ} \mathrm{C}$ for 1 $\mathrm{h}$ results in a more than 100 -fold induction of CAT expression. These expression studies under non-optimized conditions demonstrate that pCG19 and pCG30 are thermoinducible expression vectors suitable for medium overexpression of bacterial genes in E. coli.

The improved plasmid segregation stability of the constructed expression vectors was determined under selective and nonselective conditions. Cultures were grown in LB medium with $1 \mathrm{~g} / \mathrm{L}$ glucose with and without addition of tetracycline $(5 \mathrm{mg} / \mathrm{L})$ at incubation temperatures of $30^{\circ}$ and $42^{\circ} \mathrm{C}$ for more than 40 generations. The ratio of cells harboring plasmids was determined by comparison of colony-forming units (cfu) on agar plates containing or lacking tetracycline every 5 generations. However, no plasmid segregation was detected, even in cultures incubated at $42^{\circ} \mathrm{C}$ without addition of tetracycline. This implies that because of the par locus located on the expression vectors, transcription from the powerful $p_{\mathrm{R}}$ promoter does not lead to increased 
plasmid segregation even under nonselective conditions.

Also, derivatives of the described low-copy-number vectors were successfully used for moderate overexpression of E. coli homoserine kinase and aspartokinase in strains of $E$. coli (data not shown).

\section{REFERENCES}

1.Dong, H., L. Nilsson and C.G. Kurland. 1995. Gratuitous overexpression of genes in Escherichia coli leads to growth inhibition and ribosome destruction. J. Bacteriol. 177:1497-1504.

2.Kim, J.-Y., H.A. Kang and D.D.Y. Ryu. 1993. Effects of the par locus on the growth rate and structural stability of recombinant cells. Biotechnol. Prog. 9:548-554.

3.Kumar, P.K.R., H.-E. Maschke, K. Friehs and K. Schügerl. 1991. Strategies for improving plasmid stability in genetically modified bacteria in bioreactors. Trends Biotechnol. 9:279-283.

4.Lerner, C.G. and M. Inouye. 1990. Low copy number plasmids for regulated low-level expression of cloned genes in Escherichia coli with blue/white insert screening capability. Nucleic Acids Res. 18:4631.

5.Meacock, P.A. and S.N. Cohen. 1980. Nucleotide sequence of the partition locus of Escherichia coli plasmid pSC101. Cell 201:529542.

6.Poindexter, K. and R.B. Gayle III. 1991. Induction of recombinant gene expression in $E s$ cherichia coli using an alkaline $\mathrm{pH}$ shift. Gene 97:125-130.

7.Queen, C. 1983. A vector that uses phage signals for efficient synthesis of proteins in Escherichia coli. J. Mol. Appl. Genet. 2:1-10.

8.Remaut, E., P. Stanssens and W. Fiers. 1981. Plasmid vectors for high-efficiency expression controlled by the $p_{\mathrm{L}}$ promoter of coliphage lambda. Gene 15:81-93.

9.Sambrook, J., E.F. Fritsch and T. Maniatis. 1989. Molecular Cloning: A Laboratory Manual, 2nd ed. CSH Laboratory Press, Cold Spring Harbor, NY.

10.Silverstone, A.E., R.R. Arditti and B. Magazanik. 1970. Catabolite-insensitive revertants of lac promoter mutants. Proc. Natl. Acad. Sci. USA 66:773-779.

11.Stoker, N.G., N.F. Fairweather and B.G. Spratt. 1982. Versatile low-copy-number plasmid vectors for cloning in Escherichia coli. Gene 18:335-341.

12.Xu, S.-y. and A. Fomenkov. 1994. Construction of pSC101 derivatives with $\mathrm{Cam}^{\mathrm{r}}$ and $\mathrm{Tet}^{\mathrm{r}}$ for selection or LacZ' for blue/white screening. BioTechniques 17:57.

The authors would like to thank $C$. Skroblin and $P$. Widawka for excellent technical assistance. We are grateful to $K$. Schmidt of the University of Osnabrück for providing us with $p C Q V 2$ and for useful discussions. This work was supported by the
German Federal Ministery of Research and Technology (Grant No. 0310626). Address correspondence to Jörn Kalinowski, Lehrstuhl für Genetik, Fakultät für Biologie, Universität Bielefeld, Postfach 1001 31, D33501 Bielefeld, Germany. Internet: joern @ genetik.uni-bielefeld.de

Received 23 December 1996; accepted 15 October 1997.

\section{Christian Götting1,2, Georg}

Thierbach $^{1}$, Alfred Pühler ${ }^{3}$ and Jörn Kalinowski ${ }^{3}$

${ }^{1}$ Degussa $A G$

Halle

${ }^{2}$ Institut für Laboratoriums- und Transfusionsmedizin, Herzund Diabeteszentrum NRW

Bad Oeynhausen

${ }^{3}$ Universität Bielefeld

Bielefeld, Germany
ChemiluminescenceBased RNase Protection Assays for Simultaneous Quantification of Procollagen mRNAs Containing AU-Rich Regions

\section{BioTechniques 24:366-370 (March 1998)}

Ribonuclease protection assays (RPAs) offer several advantages over other methods for the detection and quantification of specific mRNAs such as Northern or dot blots. They are highly sensitive and specific because crosshybridizations and nonspecific binding of labeled probes are eliminated by the RNase digestion step (1). An RPA allows simultaneous detection and quantification of several different transcripts in one sample by using a set of multiple antisense probes of different characteristic sizes. We are primarily interested in the regulation of collagen metabolism in the University of California at Davis line 200 (UCD-200) chickens, an animal model of human systemic sclerosis, and our test system was designed to simultaneously quantify procollagen transcripts of various types in chicken tissues.

Because we used combinations of up to five antisense probes specific for different transcripts in one lane, some of the probes yielded unexpected band patterns on the RPA blot. There appeared to be enzyme-digested regions within some of the antisense probes that did not hybridize completely to the target mRNA, causing loss of specific signals, bands of unexpected size and increased background. To overcome this problem, we performed the recommended modifications, such as reduction of hybridization and digestion temperature and the use of T1 RNase, which only cleaves next to GC residues (Figure 1). Decreasing hybridization and RNase digestion temperature was not sufficient because a second, in part even more pronounced, band appeared below the 406-bp $\alpha_{1}(\mathrm{VI})$ band, obviously resulting from incomplete alignment of the $\alpha_{1}(\mathrm{VI})$ antisense probe. The signals specific for type I collagen transcripts were diffuse and overlayed 